\title{
Biogeochemical aspects of bottom anoxia in a Mediterranean lagoon (Thau, France)
}

\author{
Philippe Souchu ${ }^{1, *}$, Anne Gasc ${ }^{1, * *}$, Yves $\operatorname{Collos}^{2}$, André Vaquer $^{2}$, Henri Tournier ${ }^{1}$, \\ Bertrand Bibent ${ }^{2}$, Jean-Marc Deslous-Paoli ${ }^{1}$ \\ ${ }^{1}$ Laboratoire Ecologie, Station IFREMER, 1 rue Jean Vilar, F-34200 Sète, France \\ ${ }^{2}$ Laboratoire d'Hydrobiologie (UMR 5556 CNRS), Université de Montpellier CC093, F-34095 Montpellier Cedex 5 , France
}

\begin{abstract}
Physical and chemical characteristics (temperature, salinity, dissolved oxygen), nutrients [dissolved inorganic nitrogen (DIN), soluble reactive phosphorus (SRP) and silicate], dissolved organic nitrogen (DON) and phosphorus and particulate matter [particulate organic carbon (POC) and nitrogen (PON) and chlorophyll a] were measured at a station located in the deepest part of the Thau lagoon $(8.5 \mathrm{~m})$. France, during a $10 \mathrm{~d}$ period of bottom anoxia in summer 1994 . The upper $8 \mathrm{~cm}$ of sediment were also analyzed for ammonium $\left(\mathrm{NH}_{4}{ }^{+}\right)$and SRP concentrations in the porewater. The study period was characterized by mean wind speed under $4 \mathrm{~m} \mathrm{~s}^{-1}$ which induced an increase of surface temperature from 18 to $29^{\circ} \mathrm{C}$ with the formation of a thermocline. The correlation $\left(p<10^{-4}\right)$ between the wind speed averaged over the previous day and the difference between bottom and surface temperatures showed that the wind constituted the main vector of vertical mixing. The lack of wind led to dissolved oxygen depletion in the bottom $2 \mathrm{~m}$ and to a strong porosity increase in the upper $10 \mathrm{~cm}$ of sediment $(80$ to $>95 \%)$. Anoxic conditions increased $\mathrm{NH}_{4}{ }^{+}$and SRP concentrations in porewater from $231 \pm 89$ to $1305 \pm 305( \pm \mathrm{SD}) \mu \mathrm{M}$ and from $6.6 \pm 0.8$ to $108 \pm 43 \mu \mathrm{M}$ respectively. The potential increase of $\mathrm{NH}_{4}^{+}$ concentrations in porewater estimated from the mineralization of the microphytobenthos explained $30 \%$ of the measured increase in the upper $8 \mathrm{~cm}$ of porewater. The study period was characterized by an increase in $\mathrm{NH}_{4}{ }^{*}$, SRP and dissolved Si concentrations in the bottom water column (maxima respectively $24.2,4.9$ and $57 \mu \mathrm{M}$ ). Linear regressions between nutrient concentrations in the water column and temperature revealed a strong enhancement of bottom fluxes during anoxia. Nitrate + nitrite $\left(\mathrm{NO}_{3}{ }^{-}\right.$ $+\mathrm{NO}_{2}^{-}$) were absent in anoxic waters and remained below $0.5 \mu \mathrm{M}$ in oxic waters. Monthly concentrations of SRP in the water column of the Thau lagoon from 1970 to 1994 revealed anoxia events by summer peak values corresponding to strong bottom anoxia. Nevertheless, the general trend was a decrease due to the gradual control of eutrophication which should lead to the disappearance of bottom anoxia within the next decade. A fraction of the nutrients of benthic origin was transformed into planktonic particulate matter via primary production which increased the concentrations of chl a from about 1 to $15 \mu \mathrm{g}^{-1}$. Concentrations of DON and PON in the water column were significantly correlated, suggesting that DON compounds were released by the pelagic food web but not directly by the sediment. The increase of total nitrogen (DIN + DON + PON), considering the water column as a closed box

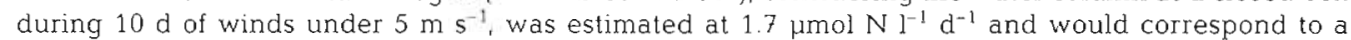
benthic flux of $600 \mu \mathrm{mol} \mathrm{N} \mathrm{m}^{-2} \mathrm{~h}^{-1}$ for $10 \mathrm{~d}$.
\end{abstract}

KEY WORDS: Anoxia N Nitrogen Phosphorus Eutrophication - Thaulagoon - Mediterranean Sea

\section{INTRODUCTION}

In shallow marine environments, microbially mediated benthic remineralization is a major recycling

-E-mail: psouchu@ifremer.fr

- Present address: Rosenstiel School of Marine and Atmospheric Science, University of Miami, 4600 Rickenbacker Causeway, Miami, Florida 33149-1098, USA pathway of settled particles (Zeitzschel 1980). Increased organic loading due to sedimentation increases oxygen consumption and excessive demand for electron acceptors can lead to oxygen depletion and to sulfate reduction within sediments. In situ experiments using benthic chambers have shown that the depletion of dissolved oxygen in the overlying water represented an additional step in the alteration of $\mathrm{N}$ and $\mathrm{P}$ cycles by a drastic increase in 
rates of nutrient release (Balzer et al. 1983, Bulleid 1984, Rutgers van der Loeff et al. 1984, Sundby et al. 1986). It is worth comparing the description of geochemical processes from artificially induced anoxic conditions with observations resulting from spontaneous bottom anoxia. However, no data on benthic release of nutrients during seasonal oxygen depletion in coastal systems are available in the literature, probably because bottom anoxia is difficult to anticipate. In a paper reporting an anoxia event in the Chesapeake Bay, USA, Officer et al. (1984) considered the positive feedback induced by anoxia on primary production in the water column as an important process to study. The enhancement of pelagic primary production by bottom anoxia cannot be studied by isolating a small volume of water from the rest of the water column. Thus, the impact of bottom anoxia on $\mathrm{N}$ and $\mathrm{P}$ cycles with regard to the coupling between the water column and sediments and the balance between organic and inorganic forms have not been properly described.

The Thau lagoon is part of the lagoonal system extending along the French Mediterranean coast and represents one of the most important shellfish breeding areas in Europe with an estimated standing stock of 25000 t of oysters (Crassostrea gigas).

The lagoon is connected to the sea by the canal of Sète. Because of the weak tidal range $(<1 \mathrm{~m})$, the residence time of water masses in the Thau lagoon mainly depends on wind and barometric effects (Millet 1989). Summer periods of 2 wk with wind velocity under $5 \mathrm{~m} \mathrm{~s}^{-1}$ can lead to oxygen depletion in bottom waters (Tournier \& Deslous-Paoli 1993), especially in the deepest shellfish farming zone, where the largest amounts of deposition occur Anoxia crises have also been described in neighbouring lagoons (Amanieu et al. 1975, Caumette \& Baleux 1980), but no data are available regarding nutrients and organic matter. However, anoxia periods are of strong interest for this ecosystem which has lost part of its shellfish production over the past decades because of mass mortality by hydrogen sulfide diffusion into the water column. This paper describes in situ biogeochemical characteristics of the water column and sediments during an occurrence of bottom anoxia and addresses the issue of eutrophication in the Thau lagoon

\section{MATERIALS AND METHODS}

The study site is part of the shellfish farming zone located in the deepest part of the Thau lagoon (Fig. 1) with muddy sediments. The sampling station was located in a corridor dividing oyster pens. Surface water $(1 \mathrm{~m})$ and bottom water $(8 \mathrm{~m})$ were sampled between 09:00 and 10:00 h from 7 June to 20 August 1994 from the research vessel 'Ostrea III' (IFREMER, Sète). The sampling rate varied from a minimal frequency of once per week in June to daily during anoxia (August). Additional stations were sampled on 4 August to assess the extent of bottom anoxia in the lagoon (Fig. 1). Sampling stations are also described in Gilbert et al. (1997), Souchu et al. (1997) and Vaquer et al. (1997). Sediments were studied before (June), during (August) and after the anoxia (September, November). All plastic materials used for sampling and chemical analyses were acid precleaned and washed with deionized water. Divers collected sediment cores by hand in $8 \mathrm{~cm}$ wide plexiglas tubes and observed the water-sediment interface. Four undisturbed $8 \mathrm{~cm}$ long cores were stored in an ice box, brought to the laboratory and processed within $2 \mathrm{~h}$ after collection. During anoxia, the first layer of sediment was carefully sampled in tripli-

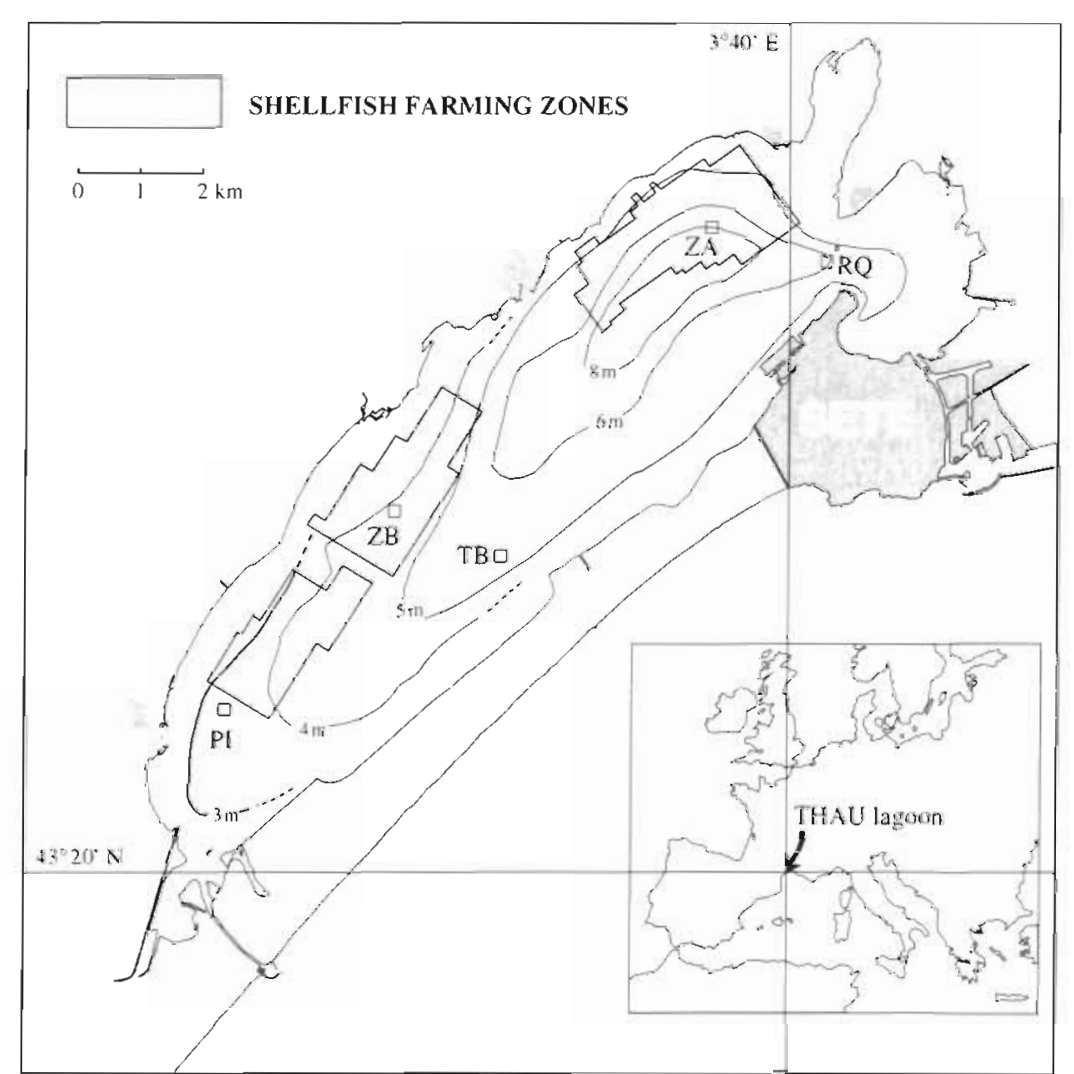

Fig. 1. Location of the study site (ZA) in the shellfish farming zone and map of the Thau lagoon showing additional sampling stations (RQ, ZB, TB, PI) 
cate with a $250 \mathrm{ml}$ syringe and stored in screw cap polycarbonate centrifuge tubes. One core was sliced into $1 \mathrm{~cm}$ sections for porosity analysis by calculation of the difference between wet and dry weight (lyophilization) and the density of dry sediment. Triplicate cores were sectioned into $1 \mathrm{~cm}$ segments inside a nitrogen-filled glove bag to minimize air oxidation of reduced species dissolved in the water. Sediment from each segment was packed into centrifuge tubes and, as well as samples for liquid sediments, centrifuged at $10000 \mathrm{rpm}(8620 \times g)$ for $15 \mathrm{~min}$ with a refrigerated centrifuge (Heraeus Megafuge 20R). Supernatant water was removed from the centrifuge tube, filtered through rinsed precombusted $\left(450^{\circ} \mathrm{C}\right.$ for $\left.6 \mathrm{~h}\right)$ Whatman GF/F filters and frozen in precombusted pyrex flasks for later analysis of ammonium $\left(\mathrm{NH}_{4}{ }^{+}\right)$and soluble reactive phosphorus (SRP) as described for the water column (see below). Interference of sulfides with Murphy \& Riley (1962) (SRP) and Berthelot $\left(\mathrm{NH}_{4}{ }^{+}\right)$colorimetric reactions were avoided by a dilution $(\times 100)$ with deionized water (De Jonge \& Villerius 1980). Data for $\mathrm{NH}_{4}{ }^{+}$porewater have been previously published in Gilbert et al. (1997).

Temperature and salinity were recorded using a WTW LF 196 conductimeter (accuracy $\pm 0.5 \%$ ). Samples for $\mathrm{O}_{2}$ measurements were carefully withdrawn from a Niskin bottle immediately after the bottle was brought on deck. Oxygen concentrations were measured by Winkler titration (Aminot 1983) with a Mettler DL 25 titrator (precision $\pm 2 \mu \mathrm{M}$ ). The saturation of $\mathrm{O}_{2}$ was derived from temperature and salinity by the Weiss (1970) equation for calculating the percentage of oxygen in relation to saturation $\left(\mathrm{O}_{2} \mathrm{SAT}\right)$. Samples for $\mathrm{NH}_{4}{ }^{+}$concentration were fixed on board and measured using the method of Koroleff (1976). Filtration and storage of samples were performed within $1 \mathrm{~h}$ after sampling. The content of the Niskin bottle was prefiltered through a $200 \mu \mathrm{m}$ screen to remove large zooplankton, stored in acid precleaned polycarbonate bottles and brought to the laboratory for filtration in an all glass filtering system through a rinsed precombusted Whatman GF/F filter (vacuum $<10 \mathrm{~cm} \mathrm{Hg}$ ). This system allowed the measurement of dissolved and particulate nitrogen forms in the same sample. Filtrates were immediately frozen in precombusted Pyrex flasks for later analysis of SRP, nitrate $\left(\mathrm{NO}_{3}{ }^{-}\right)$and nitrite $\left(\mathrm{NO}_{2}{ }^{-}\right)$with a segmented flow analyser (Tréguer \& Le Corre 1975). The simultaneous determination of dissolved organic nitrogen and phosphorus (DON and DOP) was performed using the photo-oxidation method (Armstrong \& Tibbits 1968). The filters were lyophilized and saved for later analysis of particulate organic carbon (POC) and nitrogen (PON) with a Perkin-Elmer CHN 2400 analyser. One blank filter was saved for each day of sampling and a control was per- formed every 10 samples with 0.5 to $4 \mathrm{mg}$ acetanilide standards. All analyses of nitrogen and phosphorus compounds were done in triplicate at an accuracy of 1 to $5 \%$. For soluble reactive silicate determination (Si), filtered samples were stored at $4^{\circ} \mathrm{C}$ in polycarbonate bottles until their analysis in triplicate with a segmented flow analyser at an accuracy of $1 \%$ (Tréguer \& Le Corre 1975). Chlorophyll a (chl a) was determined by a spectrofluorimetric method (Neveux \& Lantoine 1993) after filtration of $500 \mathrm{ml}$ seawater through a Whatman GF/F filter. Wind velocities were obtained from the automatic records of a meteorological station near the station ZB (CIMEL Electronique, Paris).

\section{RESULTS}

\section{Sediments}

Before the anoxic period (21 June), the sediment was composed of black mud emitting the typical hydrogen sulfide smell. The water-sediment interface was yellow-brown and partly covered by the filamentous bacteria Beggiatoa sp. Porosity was close to $80 \%$ from 1 to $8 \mathrm{~cm}$. At the beginning of August, the color of the watersediment interface turned black. In the water column, divers could distinguish the $6 \mathrm{~m}$ deep interface between the white-green turbid anoxic layer and the clear oxic upper layer. Just before the end of the anoxic period (9 August), the water column was comparable to conditions on 1 August, but the sediment displayed a $5 \mathrm{~cm}$ almost liquid upper layer, overlying a fluid mud with a porosity above $95 \%$ down to a depth of about $7 \mathrm{~cm}$. The liquid upper layer was not jelly-like and was closer to black suspended sediment than bacterial mats (Fossing et al. 1995). During anoxia, mean concentrations of SRP and $\mathrm{NH}_{4}{ }^{+}$of porewater ([SRP] and $\left[\mathrm{NH}_{4}{ }^{+}\right]$] increased in the upper $7 \mathrm{~cm}$ respectively from $6.6 \pm 0.8$ to $108 \pm 43( \pm \mathrm{SD}) \mu \mathrm{M}$ and from $231 \pm 89$ to $1305 \pm 305 \mu \mathrm{M}$ (Fig. 2). Concentration of Si in porewater, only measured during anoxia, ranged from 1350 $(1 \mathrm{~cm})$ to $700 \mu \mathrm{M}(8 \mathrm{~cm})$. In September and November, the water-sediment interface was comparable to that of June. Initial conditions were almost matched in September for porosity $(80 \%)$ and $\left[\mathrm{NH}_{4}{ }^{+}\right]$but not for [SRP], which decreased to $50 \mu \mathrm{M}$.

\section{Water column}

\section{Temperature and oxygen}

The study period (74 d) was characterized by a mean daily wind speed below $3.9 \mathrm{~m} \mathrm{~s}^{-1}$ and by temperatures in the water column ranging from $18.4^{\circ} \mathrm{C}$ 


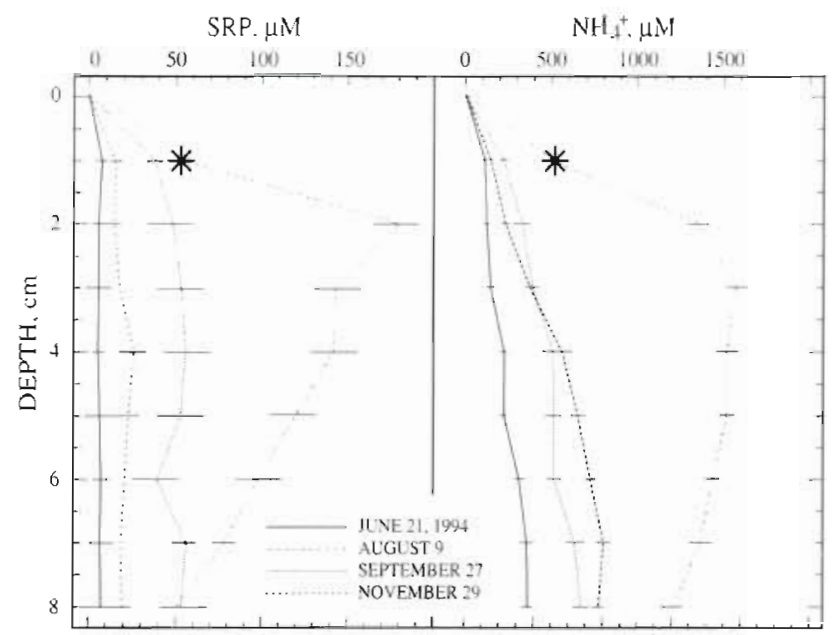

Fig. 2. Porewater profiles of [SRP] and $\left[\mathrm{NH}_{4}{ }^{+}\right]$at $\mathrm{ZA}$ from June to November 1994. Values are mean \pm standard error $(\mathrm{n}=3)$. (*) Concentrations measured in the upper $5 \mathrm{~cm}$ of hquid sediment; values at depth $=0 \mathrm{~cm}$ indicate the overlying water

in June to $29.0^{\circ} \mathrm{C}$ in August (Fig. 3). The difference between surface and bottom temperature $(\mathrm{DTemp}=$ Temp $p_{1 \mathrm{~m}}-$ Temp $_{8 \mathrm{~m}}$ ) increased from June to the end of July $\left(0\right.$ to $\left.4^{\circ} \mathrm{C}\right)$ and began to disappear at the end of August. A significant correlation $\left(\mathrm{p}<10^{-4}, \mathrm{r}^{2}=0.27\right)$ was calculated between DTemp at each sampling date and wind speed (WS) averagec over the previous day: DTemp $=3.74-0.42 \mathrm{WS}$. Salinity increased from 35.2 in June to 37.5 in August, without any difference above 0.3 between surface and bottom. In June, the percentage of oxygen in relation to saturation $\left(\mathrm{O}_{2} \mathrm{SAT}\right)$ remained close to $100 \%$ in surface and bottom waters, but decreased rapidly to $0 \%$ in July at 6 to $8 \mathrm{~m}$ (Fig. 3). In August, the appearance of anoxic conditions in a $2 \mathrm{~m}$ thick bottom layer created a strong gradient of a few centimeters between the anoxic and the oxic layer where $\mathrm{O}_{2} \mathrm{SAT}$ remained constantly above $60 \%$. Stratification and bottom anoxia were also observed outside the shellfish farming zone at the station deeper than $6 \mathrm{~m}$ (RQ; Fig. 1, Table 1).

\section{Nutrients}

Concentrations of $\mathrm{NH}_{4}^{+}\left(\left[\mathrm{NH}_{4}{ }^{+}\right]\right)$varied from $0.1 \mu \mathrm{M}$ in early June at $1 \mathrm{~m}$ to $24.2 \mu \mathrm{M}$ in August at $8 \mathrm{~m}$ (Fig. 3) and were strongly correlated ( $p<10^{-5}$ ) with $\mathrm{O}_{2} \mathrm{SAT} \cdot\left[\mathrm{NH}_{4}{ }^{+}\right]=8.8-0.84 \mathrm{O}_{2} \mathrm{SAT}\left(\mathrm{r}^{2}=-0.52\right)$. The difference between surface and bottom $\left[\mathrm{NH}_{4}{ }^{+}\right]_{\text {, }}$ $\left(\mathrm{DNH}_{4}{ }^{+}=\left[\mathrm{NH}_{4}{ }^{+}\right]_{8 \mathrm{~m}}-\left[\mathrm{NH}_{4}{ }^{+}\right]_{1 \mathrm{~m}}\right)$ and DTemp were also significantly correlated $\left(p<0.05, r^{2}=0.12\right)$. Similarly to $\mathrm{NH}_{4}^{-}$, bottom maxima in SRP $(0.12$ to $4.9 \mu \mathrm{M})$ and Si $(1.4$ to $57 \mu \mathrm{M})$ concentrations also appeared with
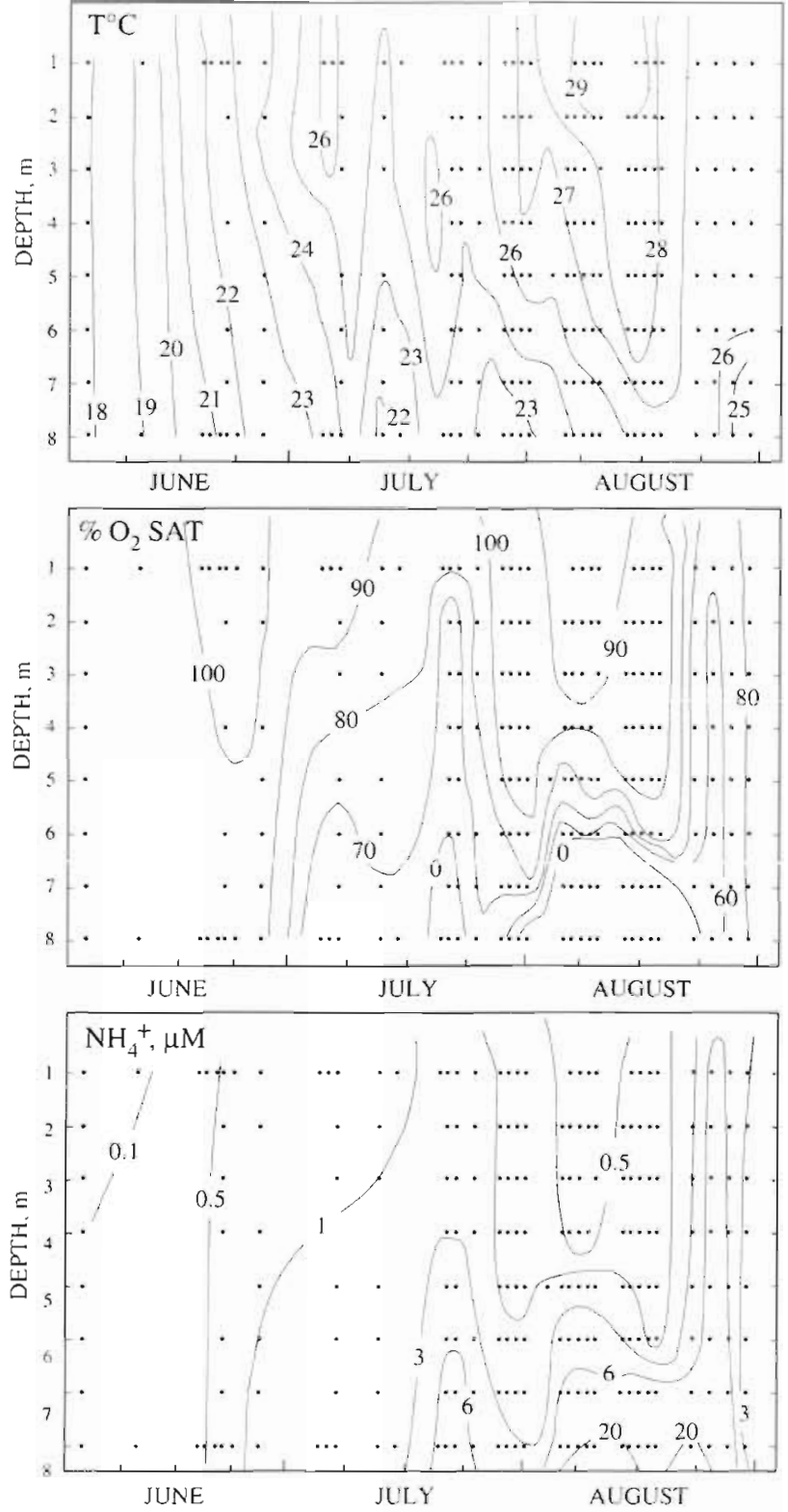

Fig. 3. Distribution of temperature, $\mathrm{O}_{2} \mathrm{SAT}$ and $\left[\mathrm{NH}_{4}^{+}\right]$in the water column at ZA from June to August 1994

anoxia, but an earlier bottom maximum appeared for [Si] at the end of June (Fig. 4). The slope of the regression between temperature and [SRP] was doubled from surface to bottom waters and was increased 4 -fold when bottom waters became anoxic (Fig. 5). Concentrations of $\mathrm{NH}_{4}^{+}$and temperature showed a comparable relationship, but anoxic conditions changed the relationship between [SRP] and $\left[\mathrm{NH}_{4}{ }^{*}\right]$ (Fig. 6). Anoxia increased the slope of the regression between [SRP] and $\left[\mathrm{NH}_{4}{ }^{+}\right]$(Table 2) by more than 2-fold, but did not change the relationship between $\left[\mathrm{NH}_{4}^{+}\right]$and [Si] significantly. The non- 
Table 1. Main biogeochemical characteristics of bottom (b) and surface (s) waters sampled at different sites on 4 August $Z A$ is the routine station

\begin{tabular}{|c|c|c|c|c|c|c|c|}
\hline Stn & $\begin{array}{l}\text { Depth } \\
(\mathrm{m})\end{array}$ & $\begin{array}{c}\text { Temp. } \\
\left({ }^{\circ} \mathrm{C}\right)\end{array}$ & $\begin{array}{c}\mathrm{O}_{2} \mathrm{SAT} \\
(\%)\end{array}$ & $\begin{array}{l}\mathrm{NH}_{4}{ }^{+} \\
(\mu \mathrm{M})\end{array}$ & $\begin{array}{l}\text { SRP } \\
(\mu \mathrm{M})\end{array}$ & $\begin{array}{c}C h l a \\
\left(\mu \mathrm{g} \mathrm{l}^{-1}\right)\end{array}$ & $\begin{array}{l}\text { PON } \\
(\mu M)\end{array}$ \\
\hline ZAs & 1.0 & 28.0 & 95 & 0.76 & 0.88 & 2.5 & 3.4 \\
\hline ZAb & 8.0 & 25.1 & 0 & 12.2 & 2.9 & 7.6 & 12.0 \\
\hline RQs & 1.0 & 27.3 & 85 & 2.32 & 0.82 & 2.0 & 4.9 \\
\hline RQb & 6.5 & 25.2 & 0 & 17.7 & 3.8 & 6.9 & 7.2 \\
\hline ZBs & 1.0 & 28.2 & 87 & 0.37 & 1.65 & 6.5 & 6.0 \\
\hline $\mathrm{ZBb}$ & 5.0 & 28.1 & 66 & 1.39 & 2.9 & 5.4 & 7.1 \\
\hline TBs & 1.0 & 27.5 & 111 & 0.52 & 1.8 & 5.1 & 4.2 \\
\hline $\mathrm{TBb}$ & 5.0 & 27.4 & 103 & 0.42 & 2.0 & 3.8 & 5.2 \\
\hline Pls & 1.5 & 28.1 & 100 & 0.51 & 1.46 & 2.8 & 4.3 \\
\hline
\end{tabular}

significant correlations between Si and other nutrients for oxic bottom waters were due to high [Si] measured from late June to early July. A significant correlation was obtained by excluding the 4 data
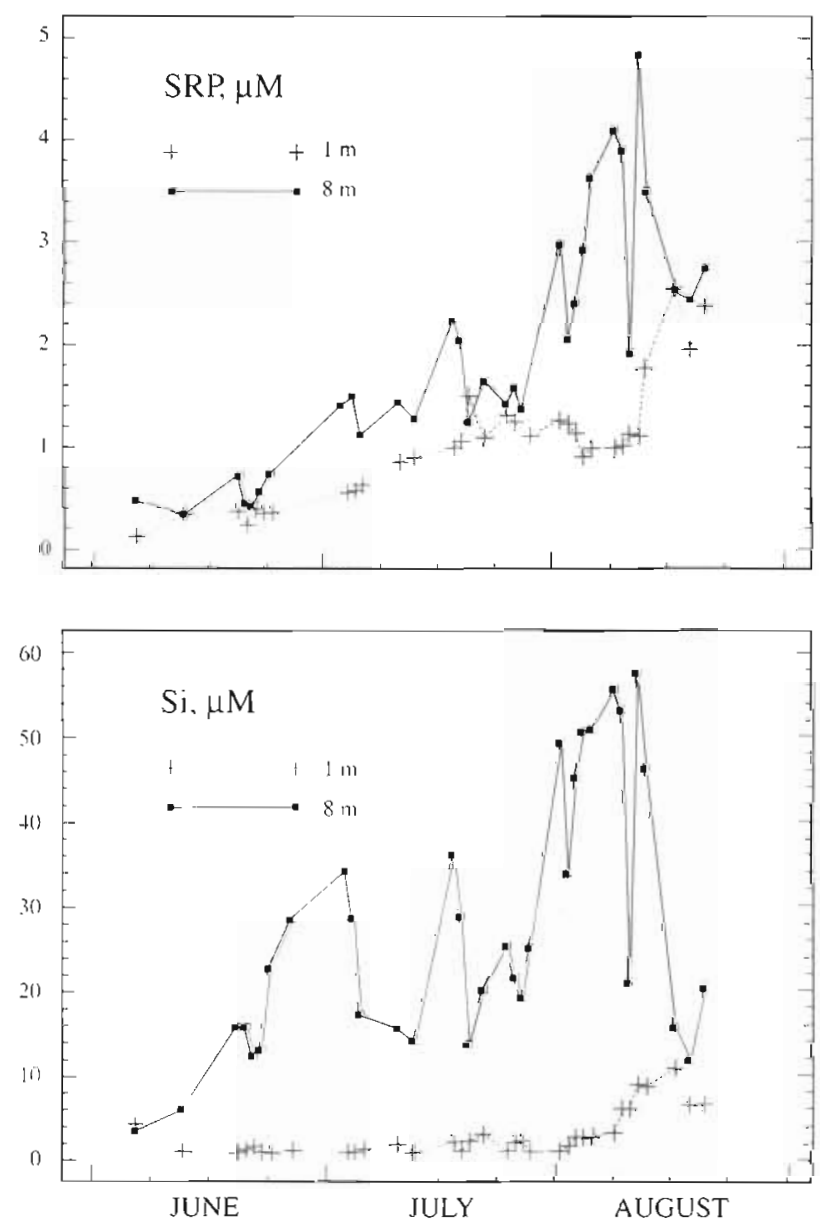

Fig. 4. Time course of [SRP] and [Si] in bottom (solid line) and surface water (dashed line) at ZA from June to August 1994. Shaded areas indicate anoxia in bottom water

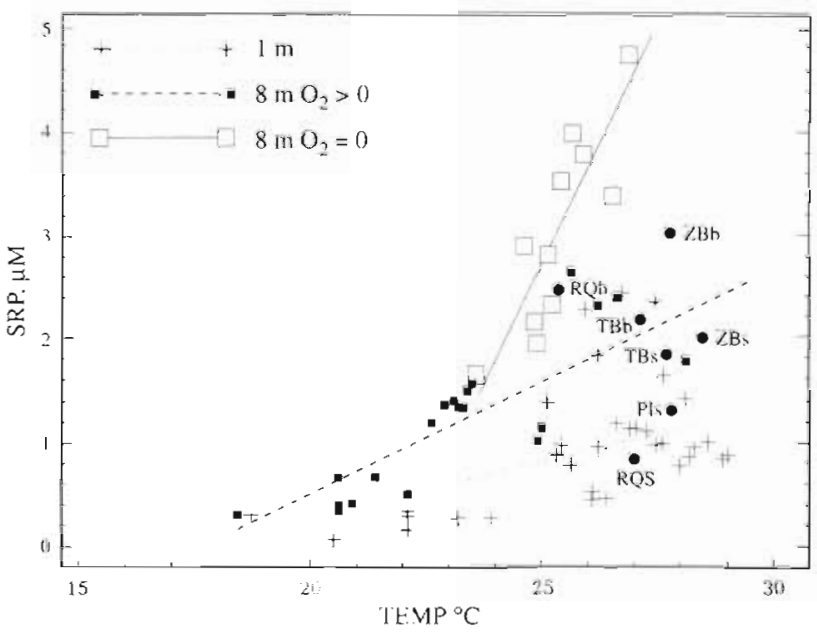

Fig. 5. [SRP] versus water temperature at ZA for surface (slope $=0.12, \mathrm{r}^{2}=0.30, \mathrm{p}=0.001$ ), oxic bottom (slope $=0.25, \mathrm{r}^{2}=0.72$, $\mathrm{p}<10^{-5}$ ) and anoxic bottom waters (slope $=0.95, \mathrm{r}^{2}=0.69$, $\mathrm{p}<10^{-5}$ ) between June and August 1994. Additional stations are labelled as in Table 1

values reported from 24 June to 5 July $\left(p<0.03, r^{2}=\right.$ $0.24)$. These high values led aiso to high [Si]:[ $\left[\mathrm{NH}_{4}{ }^{+}\right]$ ratios in bottom water $(10$ to 42 ). But during the bottom anoxia, [Si]: $\left[\mathrm{NH}_{4}{ }^{+}\right]$ratios were lower and less variable $(3.3 \pm 0.7 ; \pm \mathrm{SD})$. Concentrations of $\mathrm{NO}_{3}{ }^{-}$ and $\mathrm{NO}_{2}^{-}$(not shown) remained below the limits of detection for anoxic waters but varied from 0.03 to $0.41 \mu \mathrm{M}(0.18 \pm 0.11)$ and from 0.02 to $0.29 \mu \mathrm{M}$ $(0.08 \pm 0.05)$ for surface oxic and bottom oxic waters respectively. For oxic waters, strong correlations ( $\mathrm{p}<$ $\left.10^{-5}\right)$ were found between $\left[\mathrm{NH}_{4}^{+}\right]$and $\left[\mathrm{NO}_{2}^{-}\right]\left(\mathrm{r}^{2}=\right.$ $0.60)$ and between $\left[\mathrm{NO}_{2}{ }^{-}\right]$and $\left[\mathrm{NO}_{3}{ }^{-}\right]\left(\mathrm{r}^{2}=0.52\right)$, without variation between surface and bottom.

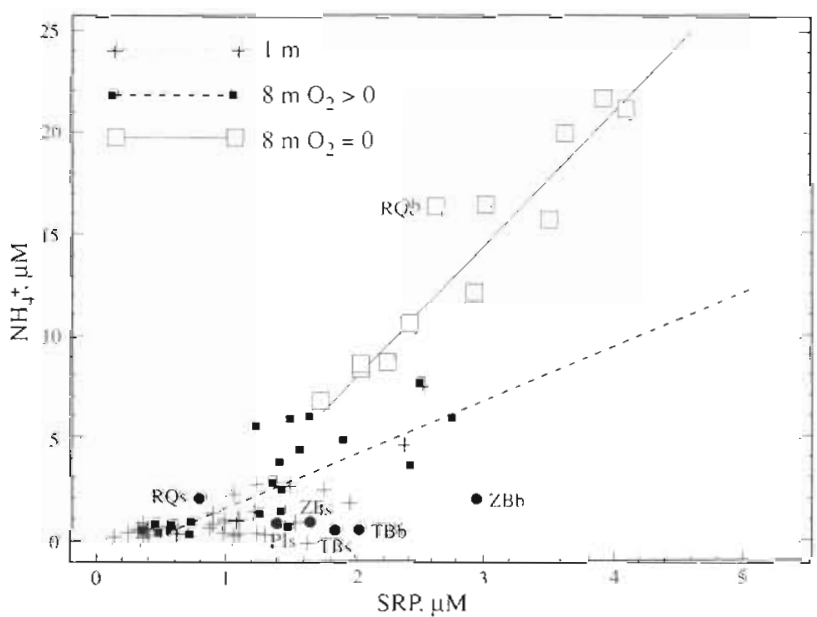

Fig. 6. $\left[\mathrm{NH}_{4}^{+}\right]$versus [SRP] at $\mathrm{ZA}$ for surface, oxic bottom and anoxic bottom waters between June and August 1994. Additional stations are labelled as in Table 1 
Table 2. Correlations between nutrient concentrations ( $\mu \mathrm{M})$ at ZA in the Thau lagoon in summer 1994 (linear model). $z$ : depth

\begin{tabular}{|c|c|c|c|}
\hline Set of data & Relationship & $\begin{array}{c}\text { Number of } \\
\text { samples }\end{array}$ & $\mathrm{r}^{2}$ \\
\hline $\begin{array}{l}z=1 \mathrm{~m} \\
z=8 \mathrm{~m}, \mathrm{O}_{2}>0 \\
z=8 \mathrm{~m}_{1} \mathrm{O}_{2}=0\end{array}$ & $\begin{array}{l}\mathrm{NH}_{4}^{+}=2.1 \mathrm{SRP}-0.8 \\
\mathrm{NH}_{4}^{+}=2.7 \mathrm{SRP}-0.8 \\
\mathrm{NH}_{4}^{+}=6.1 \mathrm{SRP}-3.7\end{array}$ & $\begin{array}{l}31 \\
20 \\
11\end{array}$ & $\begin{array}{l}0.62^{\cdots} \\
0.66^{\cdots} \\
0.94^{\cdots}\end{array}$ \\
\hline $\begin{array}{l}z=1 \mathrm{~m} \\
z=8 \mathrm{~m}_{1} \mathrm{O}_{2}>0 \\
z=8 \mathrm{~m}_{1} \mathrm{O}_{2}=0\end{array}$ & $\begin{array}{l}\mathrm{Si}=5.7 \mathrm{SRP}+0.4 \\
\mathrm{Ms} \\
\mathrm{Si}=9.9 \mathrm{SRP}+14.4\end{array}$ & $\begin{array}{l}31 \\
20 \\
11\end{array}$ & $\begin{array}{l}0.58 \cdot \\
0.12 \\
0.81\end{array}$ \\
\hline $\begin{array}{l}z=1 \mathrm{~m} \\
z=8 \mathrm{~m}_{1} \mathrm{O}_{2}>0 \\
z=8 \mathrm{~m}_{1} \mathrm{O}_{2}=0\end{array}$ & $\begin{array}{l}\mathrm{Si}=2.0 \mathrm{NH}_{4}^{+}+36 \\
\mathrm{~ns} \\
\mathrm{Si}=1.6 \mathrm{NH}_{4}^{+}+21\end{array}$ & $\begin{array}{l}32 \\
20 \\
11\end{array}$ & $\begin{array}{l}0.56^{\circ} \\
0.01 \\
0.79^{\circ}\end{array}$ \\
\hline$\because p<10^{-5} ; \cdot p<$ & $0^{-4} ;$ ns: non-signific & & \\
\hline
\end{tabular}

\section{Particulate matter}

Concentrations of chlorophyll a ([chl a]) varied from $0.1 \mu \mathrm{g} \mathrm{l}^{-1}$ in early June at $1 \mathrm{~m}$ to $15.0 \mathrm{\mu g} \mathrm{l}^{-1}$ in August at $8 \mathrm{~m}$ (Fig. 7). The strong maximum in August started in bottom waters with the deveiopment of anoxic conditions. During anoxia, mean concentrations at $8 \mathrm{~m}$ were twice those of the surface layer for chl a as well as for PON (Fig. 7) and POC (not shown). The same feature was observed on 4 August at Stn RQ, but not at the well-mixed stations for which surface waters were the most concentrated in chl a (Table 1). A strong correlation $\left(\mathrm{p}<10^{-5}\right)$ was found between [POC] and [PON] $\left([\mathrm{POC}]=3.6+7.9[\mathrm{PON}], \mathrm{p}<10^{-5}, \mathrm{r}^{2}=0.96\right)$ which was improved by adding stations sampled on 4 August $\left(\mathrm{r}^{2}=\right.$ 0.98). This relationship did not vary from surface to bottom, nor from oxic to anoxic waters. Concentrations of chl a were correlated with [PON], but the regression for anoxic waters was characterized by an intercept twice as high as for oxic ones (Fig. 8). This discrepancy between oxic and anoxic waters was also found at Stn RQ.

\section{Dissolved organic matter}

Concentrations of dissolved organic nitrogen ([DON]) varied from 1.9 to $45 \mu \mathrm{M}$ (Fig. 9) and were not cycled with those of nutrients (no significant correlation). Nevertheless, the maximum (4 July) corresponded to a bottom [chl a] maximum and significant correlations were calculated between concentrations of DON and PON (Fig. 10). The total correlation was slightly improved ( $p=0.00018$ ) by adding the other stations sampled on 4 August. Concentrations of DOP ranged from 0.35 to $2.5 \mu \mathrm{M}$ with strong variations between bottom and surface (Fig. 9). Moreover, lags of several days between surface and bottom maxima were also
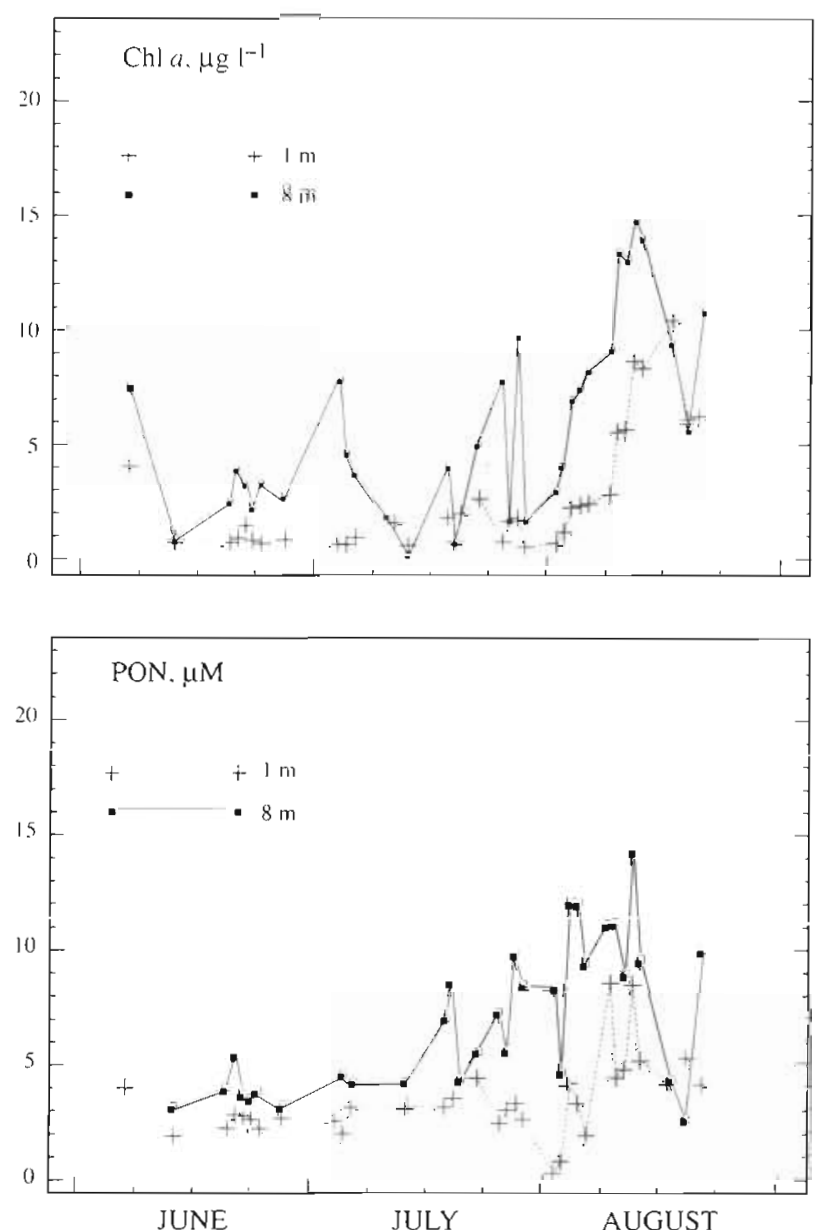

Fig. 7. Time course of [chI a] and [PON] in bottom (solid line) and surface water (dashed line) at ZA from June to August 1994. Shaded areas indicate anoxia in bottom water

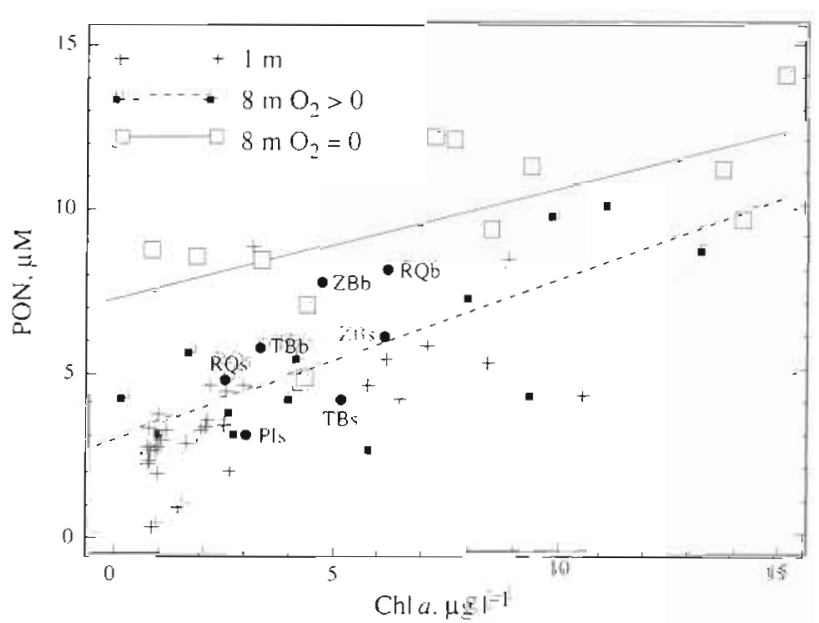

Fig. 8. Regression between [PON] and [chl a] for surface $\left(\mathrm{r}^{2}=\right.$ $0.42, p=0.00005, n=32)$, oxic bottom $\left(r^{2}=0.48, p=0.00005\right.$, $\mathrm{n}=20)$ and anoxic bottorn water $\left(\mathrm{r}^{2}=0.30, \mathrm{p}=0.02, \mathrm{n}=11 \mathrm{j}\right.$ at ZA from June to August 1994. Additional stations are labelled as in Table 1 

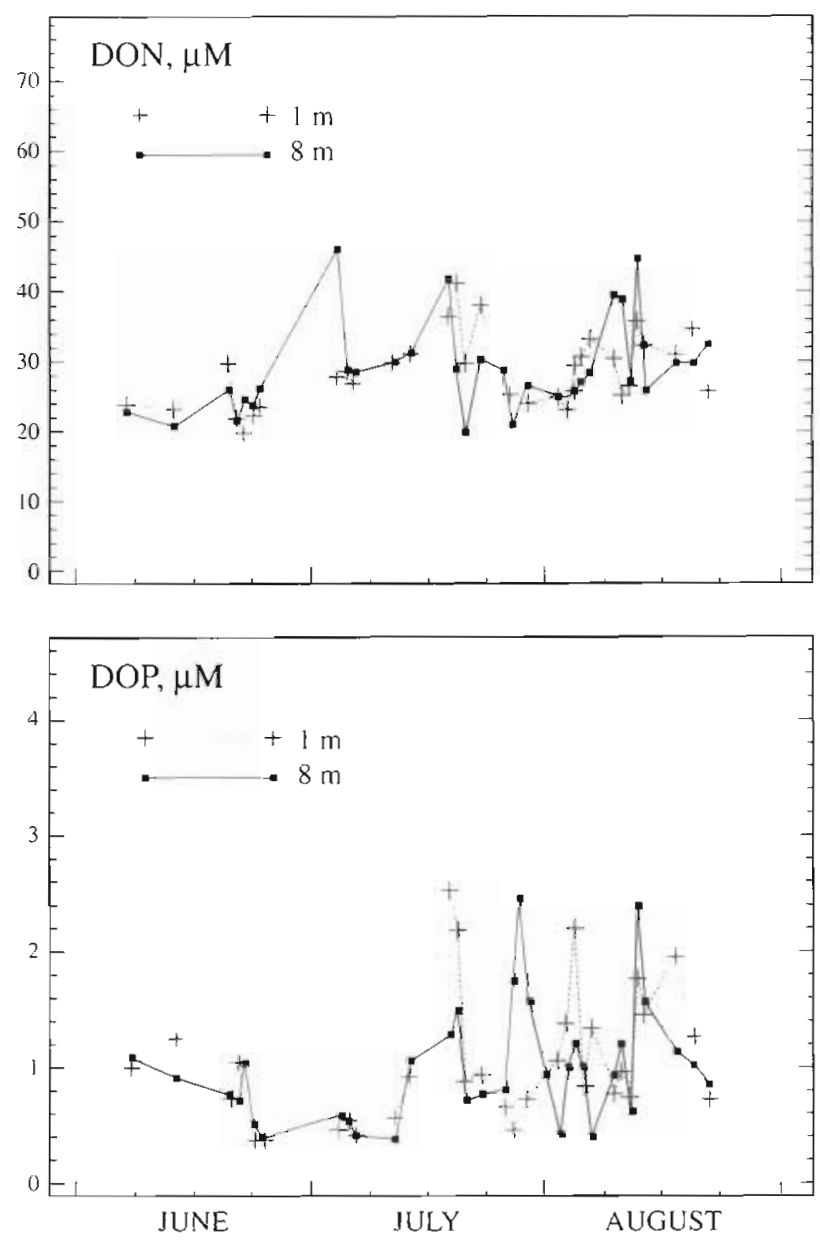

Fig. 9. Time course of [DON] and [DOP] in bottom (solid line) and surface water (dashed line) at ZA from June to August 1994. Shaded areas indicate anoxia in bottom water

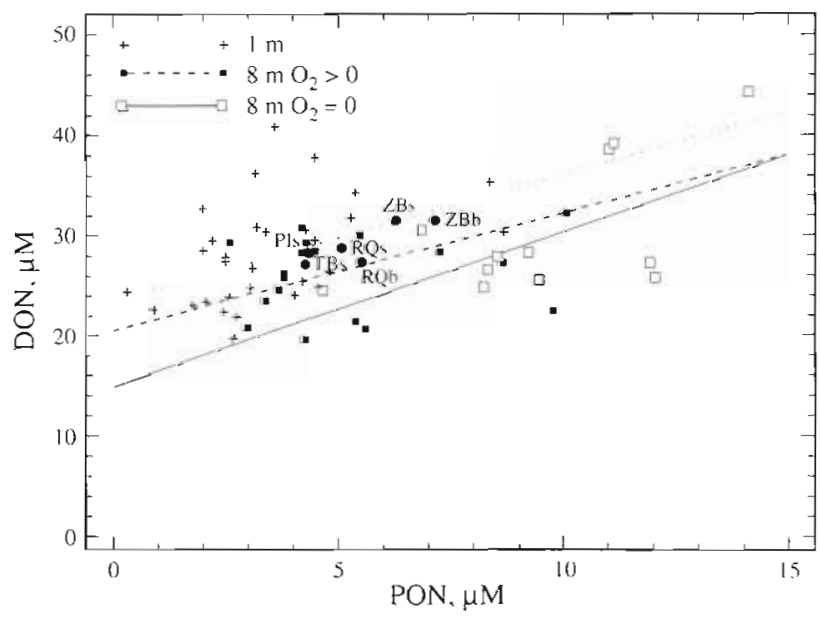

Fig. 10. Regression between [DON] and [PON] for surface $\left(\mathrm{r}^{2}=0.20, \mathrm{p}=0.015, \mathrm{n}=30\right)$, oxic bottom $\left(\mathrm{r}^{2}=0.35, \mathrm{p}=0.007\right.$, $\mathrm{n}=20)$ and anoxic bottom water $\left(\mathrm{r}^{2}=0.36, \mathrm{p}=0.038, \mathrm{n}=11\right) \mathrm{at}$ ZA from June to August 1994. Additional stations are labolled as in Table 1 observed for [DOP] during August. Maximum concentrations were measured during the anoxic period but no significant correlation was found between [DOP] and other parameters. Atomic N:P ratios in DOM ranged from 9 to 80 for a mean value of $35 \pm 17$ ( \pm SD).

\section{DISCUSSION}

\section{Physical aspects}

The spatial survey of 4 August (Table 1 ) showed that bottom anoxia occurred at stations deeper than $6 \mathrm{~m}$ displaying thermal stratification ( $\mathrm{ZA}$ and $\mathrm{RQ}$ ). The thermocline prevented oxygen of atmospheric origin from diffusing into bottom waters (Roden \& Tuttle 1992). The correlation between the wind speed averaged over the previous day and the difference between surface and bottom temperature (DTemp) showed that winds were the main source of vertical mixing. The POM concentrations in the water column were low before the decrease of $\mathrm{O}_{2}$ concentrations ([chl a] $<5 \mu \mathrm{g}$ $\mathrm{l}^{-1}$ ) and therefore the major factor contributing to the oxygen depletion was not the respiration in bottom water as in Chesapeake Bay (Taft et al. 1980). In the Thau lagoon, the oxygen utilization in sediments dominated the loss process and the low oxygen event was not due to the accumulation of recently settled particles. The anoxia observed in bottom water of areas not influenced by biodeposition indicated clearly that shellfish farming activities were not the primary cause of oxygen depletion.

Porosity is an important parameter for diffusive processes at the water-sediment interface and the drastic changes in physical properties must be taken into account for modelling. The increase of porosity in surficial anoxic sediment has been mentioned in previous papers: Sampou \& Oviatt (1991) noted an increase of porosity in the upper $6 \mathrm{~cm}$ of sediment in mesocosms with high organic content; Blackburn et al. (1988) observed 'flocculation' in the upper $2 \mathrm{~cm}$ of sediment from fishponds; Roden \& Tuttle (1992) also noticed 'flocculent sediments'

Johnson (1974) observed in a microscopic study of coastal marine sediments (Woods Hole, MA, USA) that nearly all of the clay and silt size particles were incorporated in an organic matrix made of living organisms (diatoms, fungi and bacteria) and other binding organic materials. Considering analogous sediments in the Thau lagoon, death and remineralization of these organisms via an extended period of anoxia should transform large quantities of particulate matter into dissolved compounds and could then increase porosity via the dissolution process, but this hypothesis must be verified with specifically focused studies. 


\section{Behaviour of nutrients in sediment}

Dissolved inorganic nitrogen

To our knowledge, there is no publication available as a basis for a strict comparison between our results and the literature. The increase of $1100 \mu \mathrm{M} \mathrm{NH}_{4}{ }^{+}$in porewater from the shellfish farming zone is similar to that reported beneath marine fish cages from March to October in a shallow fjord (Holmer \& Kristensen 1992). The oxygen depletion led to the decay and remineralization of benthic and pelagic organisms which could not withstand the anoxic conditions. Even if some species of microphytobenthos appear to be adapted to the presence of sulfide ions (Kennett \& Hargraves 1985), it is likely that microphytobenthic communities were killed by sulfide, leading to increased detrital organic matter in surficial sediments. Biomasses of benthic microflora range from 50 to $250 \mu \mathrm{g} \mathrm{chl} a \mathrm{~m}^{-2}$ at ZB (Barranguet et al. 1994) and summer biomasses recorded at $\mathrm{ZA}$ are close to $100 \mathrm{\mu g}$ chl a m $\mathrm{m}^{-2}$ (Plante-Cuny et al. unpubl. data). Assuming a C:chl a ratio of $30: 1$ (Strickland 1960) and a C:N ratio of 10:1 (Sundbäck. \& Granéli 1988), we calculated that the remineralization of benthic microflora nitrogen to $\mathrm{NH}_{4}{ }^{+}$would potentially increase the concentration by $350 \mu \mathrm{M}$ in the upper $8 \mathrm{~cm}$ of interstitial water. In spite of the uncertainties on C:chl $a$ and $\mathrm{C}: \mathrm{N}$ ratios, this rough calculation tends to support the hypothesis that mineralization processes produced almost all the $\mathrm{NH}_{4}{ }^{+}$in porewater

\section{Soluble reactive phosphorus}

Considering the increase of $1100 \mu \mathrm{M} \mathrm{NH}_{4}{ }^{+}$in porewater and assuming an atomic N:P ratio close to 16 in the recycled organic matter, the increase in [SRP] should amount to about $70 \mu \mathrm{M}$, which corresponds to only $60 \%$ of the measured increase. In the Thau lagoon, the release of phosphates adsorbed onto $\mathrm{Fe}(\mathrm{OOH})$, but also onto $\mathrm{CaCO}_{3}$, is maximum in summer due to minimum redox and $\mathrm{pH}$ (Mesnage \& Picot 1995). The extension of high [SRP] in porewater to at least 1 mo after the end of the anoxic pcriod could result from the reduced formation of sorption sites on $\mathrm{Fe}(\mathrm{OOH})$ owing to $\mathrm{FeS}$ (or $\mathrm{FeS}_{2}$ ) precipitation (Jensen et al. 1995). The additional increase of [SRP] in porewater should then be controlled by adsorptiondesorption processes (Watanabe \& Tsunogai 1984).

\section{Behaviour of nutrients in the water column}

Dissolved inorganic nitrogen

The set of data from the water column was collected during a well contrasted situation due to a dry period with low wind. Therefore, inputs of nutrients from Mediterranean waters or from the watershed could be considered as insignificant sources for the water column in this sector of the lagoon. It is thus likely that the strong increase of nutrients in the water column was of benthic origin. In spite of its central role in the productivity of coastal ecosystems, $\mathrm{NH}_{4}{ }^{+}$has been studied only recently in the Thau lagoon (Casellas et al. 1990 , picot et al. 1990). For this reason, anoxic bottom samples are the most concentrated in $\mathrm{NH}_{4}{ }^{+}$which have been reported for this ecosystem. Before the bottom anoxia (June), $\left[\mathrm{NH}_{4}{ }^{+}\right]:[\mathrm{SRP}]$ ratios in porewater were largely above 16, the Redfield ratio (Table 3). However, the low $\left[\mathrm{NH}_{4}{ }^{+}\right]$: [SRP] ratios in benthic fluxes measured in the Thau lagoon by Mazouni et al. (1996) and those measured in the water column (Table 3) indicate a strong deficit in $\mathrm{N}^{-} \bar{H}_{4}$ ' diiffusion at the water sedimeni interface. Picot et al. (1990) calculated analogous $\left[\mathrm{NH}_{4}{ }^{+}\right]$:[SRP] ratios of 1.6 in oxic waters sampled in summer 1986 and suggested that $\mathrm{NH}_{4}{ }^{+}$limited the summer phytoplankton production in the Thau lagoon. Nitrification, nitrate reduction to ammonium and denitrification have been measured by Gilbert et al. (1997) in sediments from ZA before and after the bottom anoxia. Their results showed that June was characterized by insignificant nitrification rates both inside (ZA) and outside the shellfish farming zone. Therefore, the nitrification-denitrification coupling was not responsible for the low $\mathrm{NH}_{4}{ }^{+}$benthic fluxes. Other results of benthic fluxes measured in the Thau lagoon with dark and transparent chambers by Barranguet et al. (1994) indicate clearly the role of photosynthetic organisms in the sequestration of nutrients at the water-sediment interface. Undoubtedly microphytobenthos was largely responsible for the 24 -fold difference between ratios in porewater and those in the water column measured before anoxia. During anoxia (August), the $\left[\mathrm{NH}_{4}{ }^{+}\right]:[\mathrm{SRP}]$ ratio in porewater dropped

Table 3. $\left[\mathrm{NH}_{+}^{-}\right]$:[SRP] ratios in porewater and underlying water from the Thau lagoon before, during and after bottom anoxia

\begin{tabular}{|c|c|c|c|c|}
\hline & June 1994 & August & September & November \\
\hline $\begin{array}{l}{\left[\mathrm{NH}_{4}{ }^{+}\right]:[\mathrm{SRP}]} \\
\text { porewater }\end{array}$ & $34 \pm 11$ & $13 \pm 5$ & $9.5 \pm 2.5$ & $26.5 \pm 9.5$ \\
\hline $\begin{array}{l}{\left[\mathrm{NH}_{4}{ }^{*}\right]:[\mathrm{SRP}]} \\
\text { water column }\end{array}$ & $1.4 \pm 0.9$ & $\begin{array}{l}4.7 \pm 0.6, \mathrm{O}_{2}=0 \\
1.9 \pm 1.0, \mathrm{O}_{2}>0\end{array}$ & $3.6 \pm 1.0$ & $6.8 \pm 2.0$ \\
\hline
\end{tabular}


below the Redfield ratio due to the strong increase of [SRP] (Table 3). This theoretical preferential release of SRP into the water column should have contributed to decreasing the ratios in the water column. However, the ratio increased significantly in bottom water, even if it never reached the Redfield ratio. The strong correlations between $\left[\mathrm{NH}_{4}^{+}\right]$and $\left[\mathrm{NO}_{2}^{-}\right]$and between $\left[\mathrm{NO}_{2}^{-}\right]$ and $\left[\mathrm{NO}_{3}{ }^{-}\right]$indicate that nitrification occurred in oxic waters. But, as far as the low $\left[\mathrm{NO}_{3}{ }^{-}\right]$is concerned, this process was not thought to unbalance the $\left[\mathrm{NH}_{4}^{+}\right]$: [SRP] ratios significantly. The explanation for the higher $\left[\mathrm{NH}_{4}{ }^{+}\right]:[\mathrm{SRP}]$ ratios in anoxic bottom waters can be found in the breakdown of benthic primary producers which may have decreased the uptake of $\mathrm{NH}_{4}{ }^{+}$at the water-sediment interface.

\section{Dissolved silicate}

Concentrations of Si above $50 \mu \mathrm{M}$ recorded in this study are close to the maximum values reported in the Thau lagoon by Tournier et al. (1982). The earlier increase of bottom $\mathrm{Si}$ concentrations relative to $\mathrm{NH}_{4}{ }^{+}$ and SRP, which corresponds to the sharpest increase of temperature (Fig. 3), denotes processes other than microbial mineralization or desorption. The release of Si from sediments was due mainly to the dissolution of opaline silica (from pelagic and benthic diatom tests) and was directly controlled by temperature (Aller \& Benninger 1981). In contrast to $\mathrm{NH}_{4}^{+}$and SRP, anoxic conditions are not supposed to enhance benthic Si fluxes (Balzer et al. 1983, Bulleid 1984) and should rather decrease the release of Si by cessation of bioturbation (Rutgers van der Loeff et al. 1984); however, this particular behaviour of $\mathrm{Si}$ obtained from experimental results (asphyxiation technique) was not confirmed by our observations in the Thau lagoon. The strong coupling between [Si], $\left[\mathrm{NH}_{4}{ }^{+}\right]$and [SRP] in the water column (Table 2) reveals that the mineralization of benthic diatoms was a major source of nutrients in bottom water, even if additional SRP due to desorption kept $\left[\mathrm{NH}_{4}^{+}\right]$: [SRP] ratios largely below Redfield ratios.

\section{Soluble reactive phosphorus}

The SRP concentration in the water column is a good indicator of eutrophication in the Thau lagoon because this nutrient is not the main limiting nutrient and concentrations are not controlled by primary consumers as for DIN. In their investigation of Århus Bay, Jensen et al. (1995) have shown correlations between bottom water temperature, low bottom water $\mathrm{O}_{2}$ concentrations, high sulfate reduction rates and high benthic fluxes of SRP. These features also apply to the Thau lagoon where the relationship between benthic fluxes of SRP and temperature has been shown by Mazouni et al. (1996). Monthly averaged SRP concentrations and water temperature in the Thau lagoon were obtained from data collected from 1971 to 1994 between 0.5 and $3 \mathrm{~m}$ (sampling stations and methods are described in Tournier et al. 1982). Temperature in the Thau lagoon measured in August from 1971 to 1994 ranged from 21.3 to $29.0^{\circ} \mathrm{C}$ $(23.7 \pm 1.4, \pm \mathrm{SD})$. Maximum [SRP] were systematically reached in summer (Fig. 11). As an example, [SRP] concentrations measured at ZA from January 1993 to March 1994 were strongly correlated with temperature $\left(\mathrm{p}<10^{-5}, \mathrm{r}^{2}=0.58\right)$. In 1975, the peak value corresponded to the most important anoxia event recorded, which led to the mortality of all the oyster stock grown in the ZA area. In spite of higher temperatures, other anoxia events following 1975 were weaker and no mortality was recorded in summer 1994, which however corresponded to the highest temperature maximum recorded in the Thau lagoon. Moreover, winter [SRP] tend to decrease from about $3 \mu \mathrm{M}$ in 1971 to undetectable in 1994 (Fig. 11). Residuals from the regression between normalized [SRP] and water temperature were extracted for trend analysis (StatGraphics 5). The model gave a strong linear negative trend $\left(r^{2}=0.74\right)$. Therefore, temperature is not sufficient to explain the decrease of SRP in the Thau lagoon from 1971 to 1994. Redox and $\mathrm{pH}$ conditions are linked with temperature but they also depend on the loading of organic matter in the sediment, which increases sulfate reduction rate

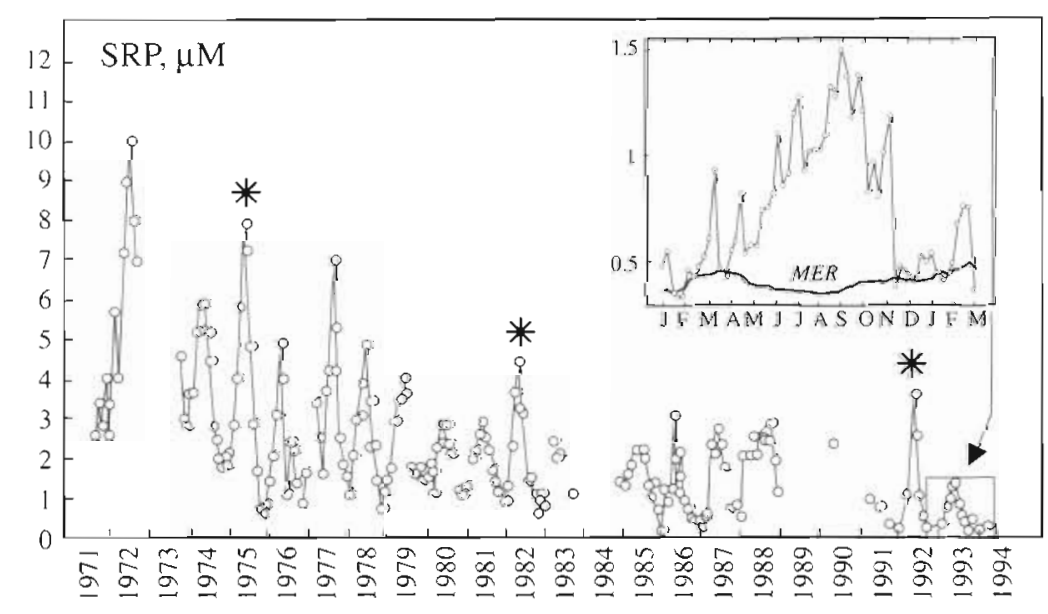

Fig. 11. Monthly [SRP] in the Thau lagoon from 1971 to 1994 and an emphasis on weekly variations at ZA. $(1 \mathrm{~m})$ from January 1993 to March 1994 with the moving average in Mediterranean waters (MER) outside the lagoon (from Souchu et al. 1997). Peak values (*) correspond to reports of oyster mortalities 
(Sampou \& Oviatt 1991). It is likely that the loading of organic matter in sediment has also decreased during the past decades. The period 1970 to 1975 corresponds to the maximum sewage inputs in this ecosystem and the most severe anoxia crisis of 1975 convinced users of the necessity of gradually improving the control of anthropogenic inputs. The surface temperature of $29^{\circ} \mathrm{C}$ measured in this study corresponds to the maximum measured in the Thau lagoon since 1970, and except for peak temperature periods, actual summer [SRP] tend to stay near $1 \mu \mathrm{M}$, which is close to values for non-eutrophicated coastal ecosystems (Pomeroy 1960). Assuming that the current purification policy will continue in the Thau lagoon, anoxia events with mass mortality can be expected to disappear in the next decade. In contrast, the drastic reduction of nutrient inputs could lead to the decline of the pelagic primary production in the Thau lagoon. Consequently. the dependence of the carrying capacity for shellfish farming upon anthropogenic nutrient sources should be quantified to avoid the decline of oyster farms.

\section{Fate of nutrients from anoxic sediment in the water column}

\section{Particulate organic matter}

The strong linear relationship between POC and PON concentrations had a slope close to the Redfield ratio in the whole water column, regardless of the oxygen concentration. Besides, the intercept gave a 'non-degradable' fraction representing $8 \%$ of the average POC, which was the same as for surface Mediterranean waters (Copin-Montégut \& Copin-Montégut 1983). The POM described in this study was therefore essentially of planktonic origin. No determination of species was performed in this study but taxonomical analysis data from the observation network REPHY (IFREMER) were available near ZA (Le Bec et al. 1997). Cell counts from this network indicated that waters were dominated by diatoms on 22 August ( $90 \%$ of phytoplanktonic cells belonged to Chaetoceros, Nitzschia and Thalassionema genera). Concentrations of chl a in the Thau lagoon can rise above $20 \mathrm{\mu g} \mathrm{l}^{-1}$ during fall and spring blooms of diatoms that are supplied. with $\mathrm{NO}_{3}^{-}$from freshwater inputs (Tournier et al. 1982, Tournier \& Pichot 1987, Jarry et al. 1990). But during the dry season, [chl a] are usually below $3 \mu \mathrm{g} \mathrm{I}^{-1}$ because the primary production is controlled by internal fluxes of $\mathrm{NH}_{4}{ }^{+}$at the water-sediment and filter feeders-water interfaces (Picot et al. 1990), and probably also by regeneration in the water column (Harrison 1978). The summer maximum in chl a and PON concentrations reported in bottom water undoubtedly corresponds to a planktonic bloom enhanced by exceptionally high nutrient fluxes of benthic origin, especially $\mathrm{NH}_{4}^{+}$. Assuming a $\mathrm{N}: \mathrm{Si}$ ratio below 1 in these species (Brzezinski 1985) and considering the $\left[\mathrm{NH}_{4}{ }^{+}\right]:[\mathrm{Si}]$ ratios in the water column, Si concentrations probably never limited their growth. The additional non-chlorophyll PON component measured in anoxic waters showed that anoxic bottom water was characterized by a fraction which was heterotrophic but not detrital in the sense of Sakshaug et al. (1983). Anoxic waters are likely to favor the proliferation of photosynthetic sulfide-oxidizing bacteria such as Chlorobiaceae and Chromaticeae (Caumette \& Baleux 1980). But, the occurrence of strictly heterotrophic bacteria in anoxic waters cannot be excluded. However, heterotrophic bacteria are known to display $\mathrm{C}: \mathrm{N}$ ratios close to 5:1 (Goldman et al. 1987), and if they developed in bottom anoxic water, heterotrophic bacteria did not lower the C:N ratios significantly.

Dissolved organic matter

Concentrations of DOM ([DON] and [DOP]) were not cycled with those of inorganic nutrients. This suggests that the general increase of [DON] and [DOP] was not directly linked with benthic fluxes, even if interstitial [DON] was not measured. Although it was weak, the correlation between [DON] and [PON] would rather suggest that DOM originated from pelagic microbial production through several processes, such as excretion, cell lysis and sloppy feeding (Goldman et al. 1985, Bronk \& Glibert 1993), but also because the GF/F filter did not retain the entire bacterioplanktonic and phytoplanktonic communities which developed in the water column. It can therefore be suggested that a substantial part of the $\mathrm{NH}_{4}^{+}$released by the sediments fueled the DON pool in the water column via primary production.

Variations of [DOP] are harder to explain since production rates can vary substantially with depth and time of day (Orrett \& Karl 1987), and also because a large part of this pool is quickly available for phytoplankton and bacteria (Bonin 1988). However, the discrepancy between [DOP] peaks in surface and bottom anoxic waters (Fig. 9) suggests the coexistence of 2 microbial communities with different behavior regarding this parameter

During bottom anoxia, the fluidization of the 5 upper $\mathrm{cm}$ of sediment rendered measurements of nutrient fluxes at the water-sediment interface with benthic chambers or core incubations unsuitable. Calculations based on $\left[\mathrm{NH}_{4}{ }^{+}\right]$increases in the water column would underestimate the benthic fluxes because uptake by primary producers leads to rapid transfer of nutrients 
to particulate and then to dissolved organic forms. For this reason, we calculated the increase of total nitrogen $([T N]=[D I N]+[D O N]+[P O N])$ in the water column. We isolated the period between 1 and 9 August, the wind velocity never exceeding $5 \mathrm{~m} \mathrm{~s}^{-1}$ and the difference between surface and bottom temperature (DTemp) increasing from 2.3 to $3.2^{\circ} \mathrm{C}$. We could thus consider the water column as a box accumulating $\mathrm{NH}_{4}{ }^{+}$of benthic origin which was transformed partly into dissolved and particulate organic forms and assume that denitrification and exportation were negligible. The concentration of $\mathrm{TN}$ in the whole water column was calculated by assigning surface concentrations to the upper $6 \mathrm{~m}$ and bottom concentrations to the rest $(2.5 \mathrm{~m})$. The relationship between [TN] and the number of days was significant: $[\mathrm{TN}]=33+1.7$ Day $\left(p<0.03, r^{2}=0.66, n=\right.$ 7 ), while no significant regression with time was found for [DIN], [DON] and [PON] taken individually. This is an additional argument for considering the DON pool as mainly coming from the water column. The increase

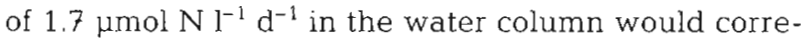
spond to a benthic flux of $600 \mu \mathrm{mol} \mathrm{m} \mathrm{m}^{-2} \mathrm{~h}^{-1}$ for $10 \mathrm{~d}$. This calculated $\mathrm{NH}_{4}{ }^{+}$flux is close to results from measurement of benthic fluxes in the Thau lagoon around periods of bottom anoxia (Mazouni et al. 1996). These results are in the same range as summer measurements reviewed by Reay et al. (1995) in silt-clay sediment, but also as those measured from sediment cores highly loaded with organic material (Sloth et al. 1995).

\section{Conclusion}

The geomorphologic properties of Mediterranean lagoons, associated with meteorological aspects, make this ecosystem particularly responsive to eutrophication. The lack of wind coupled to oxygen utilization in sediments is the primary cause of bottom anoxia in the Thau lagoon. The presence of bottom anoxia in areas away from shellfish farms showed that biodeposition was not responsible for excessive oxygen consumption. Concentrations of SRP reported from the last 3 decades indicate that organic matter in sediments has decreased since 1970 due to a better control of anthropogenic inputs. Bottom anoxia is then expected to disappear in the next decade. Nevertheless, anoxia from the border of the lagoon due to the accumulation of algal mats remains possible and this local eutrophication must still be studied.

Acknowledgements. This work is a contribution to the Oxythau project of the 'Programme National d'Océanographie Côtière' and was funded by the Conseil Général of Hérault. The authors are grateful to $C$. Juge, G. du Réault and F. Dagault for their technical assistance and thank $T$ E.
Whitledge and anonymous reviewers for their comments on the manuscript. This is a contribution of the working group URM IFREMER No. 5.

\section{LITERATURE CITED}

Aller RC, Benninger LK (1981) Spatial and temporal patterns of dissolved ammonium, manganese and silica fluxes from bottom sediments in Long Island Sound U.S.A. J Mar Res 39:295-314

Amanieu M, Baleux B, Guelorget O, Michel P (1975) Étude biologique et hydrologique d'une crise dystrophique (Malaigue) dans l'étang du Prévost à Palavas (Hérault). Vie Milieu 25:175-204

Aminot A (1983) Dosage de l'oxygène dissous. In: Aminot A, Chaussepied $M$ (eds) Manuel des analyses chimiques en milieu marin, Chap 5. CNEXO, Brest, p 75-92

Armstrong FAJ, Tibbits S (1968) Photochemical combustion of organic matter in sea water for nitrogen, phosphorus and carbon determination. J Mar Biol Assoc UK 48:143-152

Balzer W, Grasshoff $\mathrm{K}$, Dieckmann P, Haardt H, Petersohn U (1983) Redox-turnover at the sediment/water interface studied in a large bell jar system. Oceanol Acta 6:337-344

Barranguet C, Alliot E, Plante-Cuny MR (1994) Benthic microphytic activity at two Mediterranean shellfish cultivation sites with reference to benthic fluxes. Oceanol Acta $17: 211-221$

Blackburn TH, Lund BAa, Krom MD (1988) C- and Nmineralization of earthen marine fishponds. Mar Ecol Prog Ser $44: 221-227$

Bonin DJ (1988) Rôle du phosphore organique dissous dans la production primaire. Océanis 14:381-387

Bronk DA, Glibert PM (1993) Contrasting patterns of dissolved organic nitrogen released by two size fractions of estuarine plankton during a period of rapid $\mathrm{NH}_{4}{ }^{+}$consumption and $\mathrm{NO}_{2}^{-}$production. Mar Ecol Prog Ser 95:291-299

Brzezinski MA (1985) The Si:C:N ratio of marine diatoms: Interspecific variability and the effect of some environmental variables. J Phycol 21:347-357

Bulleid NC (1984) Deoxygenation and remineralization above the sediment-water interface; an in situ experimental study. Estuar Coast Shelf Sci 19:15-25

Casellas C, Péna G, Picot B, llles S, Bontoux J (1990) Structure spatiale des sels nutritifs au sein d'un écosystème lagunaire: l'étang de Thau. Wat Res 12:1479-1489

Caumette P, Baleux B (1980) Etude des eaux rouges dues à la prolifération des bactéries photosynthétiques sulfooxydantes dans l'étang du Prévost, lagune saumâtre méditerranéenne. Mar Biol 56:183-194

Copin-Montégut C. Copin-Montégut G (1983) Stoichiometry of carbon, nitrogen, and phosphorus in marine particulate matter. Deep Sea Res 30:31-46

De Jonge VN, Villerius LA (1980) Interference of sulphide in inorganic phosphate determination in natural waters. Mar Chem 9:191-197

Fossing $\mathrm{H}$, Gallardo VA, Jorgensen BB, Hüttel M, Nielsen LP, Schulz H, Canfjeld DE, Forster S, Glud RN, Gundersen JK, Küver J, Ramsing NB, Teske A, Thamdrup B, Ulloa O (1995) Concentration and transport of nitrate by the mat-forming sulphur bacterium Thioploca. Nature 374 : $713-715$

Gilbert F, Souchu P, Bianchi M, Bonin P (1997) Influence of shellfish farming activities on nitrification, nitrate reduction to ammonium and denitrification at the watersediment interface of the Thau lagoon, France. Mar Ecol Prog Ser 151:143-153 
Goldman JC, Caron DA, Andersen OK, Dennett MR (1985) Nutrient cycling in a microflagellate food chain: I. Nitrogen dynamics. Mar Ecol Prog Ser 24:231-242

Goldrnan JC, Caron DA, Dennett MR (1987) Regulation of gross growth efficiency and ammonium regeneration in bacteria by substrate C:N ratio. Limnol Oceanogr 32 : $1239-1252$

Harrison WG (1978) Experimental measurements of nitrogen remineralization in coastal waters. Limnol Oceanogr 23: $684-694$

Holmer M, Kristensen E (1992) Impact of marine fish cage farming on metabolism and sulfate reduction of underlying sediments. Mar Ecol Prog Ser 80:191-201

Jarry V, Fiala M, Frisoni GF, Jacques G, Neveux J, Panouse M (1990) The spatial distribution of phytoplankton in a Mediterranean lagoon (Etang de Thau). Oceanol Acta 13: 503-512

Jensen HS, Mortensen PB, Andersen FØ, Rasmussen $E_{1}$ Jensen A (1995) Phosphorus cycling in a coastal marine sediment, Aarhus Bay, Denmark. Limnol Oceanogr 40 : 908-917

Johnson RG (1974) Particulate matter at the sediment water interface in coastal environments. J Mar Res 32.313-330

Kennett DM, Hargraves PE (1985) Benthic diatoms and sulfide fluctuations: upper basin of Pettaquamscutt River, Rhode Island. Estuar Coast Shelf Sci 1:577-586

Koroleff F (1976) Determination of nutrients. In: Grasshoff K (ed) Methods of seawater analysis. Verlag Chemie, Weinheim, p 117-182

Le Bec C, Belin C, Gaertner JC, Beliaeff B, Raffin B, Ibanez F (1997) Séries temporelles du réseau de surveillance du phytoplancton (REPHY). Étude de deux zones de la còte Ouest Méditerranée. Oceanol Acta 20:101-1.08

Mazouni N, Gaertner JC, Deslous-Paoli JM, Landrein S, Geringer d'Oedenberg $M$ (1996) Nutrient and oxygen exchanges at the water-sediment in a shellfish farming lagoon (Thau, France). J Exp Mar Biol Ecol 205:91-113

Mesnage V, Picot B (1995) The distribution of phosphate in sediments and its relation with eutrophication of a Mediterranean coastal lagoon. Hydrobiologia 297:29-41

Millet B (1989) Fonctionnement hydrodynamique du bassin de Thau. Validation écologique d'un modèle numérique de circulation (programme Ecothau). Oceanol Acta 12:37-46

Murphy J, Riley JP (1962) A modified single solution method for the determination of phosphate in natural waters. Anal Chim Acta 27:31-36

Neveux J, Lantoine F (1993) Spectrofluorometric assay of chlorophylls and phaeopigments using the least squares approximation technique. Deep Sea Res 9:1747-1765

Officer CB, Biggs RB, Taft JL, Cronin LE, Tyler MA, Boynton WR (1984) Chesapeake Bay anoxia: origin, development and significance. Science 223:22-27

Orrett K, Karl DM (1987) Dissolved organic phosphorus production in surface seawaters. Limnol Oceanogr 32: 383-395

Picot B, Péna G, Casellas C, Bondon D, Bontoux J (1990) Interpretation of the seasonal variations of nutrients in a Mediterranean lagoon: étang de Thau. Hydrobiologia 207 : $105-114$

Pomeroy LR (1960) Residence time of cissolved phosphate in natural waters. Science 131:421-430

Reay WG, Gallagher DL, Simmons GM Jr (1995) Sedimentwater column oxygen and nutrient fluxes in nearshore

Editorial responsibility: Otto Kinne (Editor), Oldendorf/Luhe, Germany environments of the lower Delmarva Peninsula, USA. Mar Ecol Prog Ser 118:215-227

Roden EE, Tuttle JH (1992) Sulfide release from estuarine sediments underlying anoxic bottom water. Limnol Oceanogr $37: 725-738$

Rutgers van der Loeff MM, Anderson LG, Hall POJ, Iverfeldt Á, Josefson AB. Sundby B. Westerlund SFG (1984) The asphyxiation technique: an approach to distinguishing between molecular diffusion and biologically mediated transport at the sediment-water interface. Limnol Oceanogr 29:675-686

Sakshaug E, Andersen K, Myklestad S, Olsen Y (1983) Nutrient status of phytoplankton communities in Norwegian waters (marine, brackish, and fresh) as revealed by their chemical composition. J Plankton Res 5:175-196

Sampou P, Oviatt A (1991) Seasonal patterns of sedimentary carbon and anaerobic respiration along a simulated eutrophication gradient. Mar Ecol Prog Ser 72:271-282

Sloth NP, Blackburn TH, Hansen LS, Risgaard-Petersen $N$, Lomstein BAa (1995) Nitrogen cycling in sediments with difterent organic loading. Mar Ecol Prog Ser 116:163-170

Souchu P, Gasc A, Cahet G, Vaquer A, Collos Y, Deslous-Paoli JM (1997) Biogeochemical composition of Meditcrranean waters autside Thau lagoon. Estuar Coast Shelf Sci 44 : $275-284$

Strickland JDH (1.960) Measuring the production of marine phytoplankton. Bull Fish Res Bd Can 122:1-172

Sundbäck K, Granéli W (1988) Influence of microphytobenthos on the nutrient fluxes between sediment and water: a laboratory study. Mar Ecol Prog Ser 43:63-69

Sundby $B$, Anderson $L G$, Hall POJ, Iverfeldt $\AA$, Rutgers van der Loeff MM. Westerlund SFG (1986) The effect of oxygen on release and uptake of cobalt, manganese, iron and phosphate at the sediment-water interface. Geochim Cosmochim Acta 50:1281-1288

Taft J, Taylor WR, Hartwing EO, Loftus R (1980) Seasonal oxygen depletion in Chesapeake Bay. Estuaries 3:242-247

Toumier H, Deslous-Paoli JM (1993) Variation spatio-temporelle estivale de l'oxygène dans les secteurs conchylicoles de l'étang de Thau. J Rech Oceanogr 18:71-73

Tournier $H_{1}$ Hamon PY, Landrein S (1982) Synthèse des observations réalisées par l'I.S.T.P.M. sur les eaux et le plancton de Thau de 1974 à 1980. Rev Trav Inst Pêches Marit 45:283-318

Tournier H, Pichot Y (1987) Répartition de la chlorophylle A dans l'étang de Thau: richesse nutritive pour les molIusques d'élevage. Rev Trav Inst Pêches Marit 49:12-34

Tréguer P, Le Corre P (1975) Manuel d'analyse des sels nutritifs dans l'eau de mer. Utilisation de l'auto analyseur II, Technicon. L.O.C. Univ Bretagne Occidentale, Brest

Vaquer A, Troussellier M, Courties C, Bibent B (1997) Standing stock and dynamics of picophytoplankton in the Thau lagoon (northwest Mediterranean coast). Limnol Oceanogr 41:1821-1828

Watanabe Y, Tsunogai S (1984) Adsorption-desorption control of phosphate in anoxic sediment of a coastal area, Funka Bay, Japan. Mar Chem 15:71-83

Weiss RF (1970) The saturation of nitrogen, oxygen, and argon in water and sea water. Deep Sea Res 17:721-735

Zeitzschel B (1980) Sediment-water interactions in nutrient dynamics. 1n: Tenore KR, Coull BC (eds) Marine benthic dynamics. University of South Carolina Press, Columbia, p $195-218$

Submitted: October 1, 1997; Accepted: January 12, 1998

Proofs received from author(s): March 17. 1998 